\title{
PENGARUH PEMBELAJARAN LITERASI DIGITAL PADA KOMPETENSI TEKNOLOGI INFORMASI DAN KOMUNIKASI CALON GURU
}

\section{THE EFFECT OF DIGITAL LITERACY LEARNING \\ ON THE INFORMATION TECHNOLOGY AND COMMUNICATION COMPETENCY OF PRE-SERVICE TEACHER}

\author{
Prasetyo Listiaji \\ Jurusan IPA Terpadu, Fakultas Matematika dan IImu Pengetahuan Alam, \\ Universitas Negeri Semarang, Indonesia \\ Email: p.listiaji@mail.unnes.ac.id \\ Subhan Subhan \\ Jurusan Ilmu Komputer, Fakultas Matematika dan Ilmu Pengetahuan Alam, \\ Universitas Negeri Semarang, Indonesia
}

Naskah diterima tanggal: 27-04-2021, disetujui tanggal: 20-06-2021

\begin{abstract}
Currently, teachers are required to have the ability to integrate ICT in learning to answer the challenges of learning in the 21st century. One of the efforts to improve teachers' ICT competencies is to implement digital literacy learning in universities that produce prospective teacher graduates. This study aims to determine how the effect of digital literacy learning on the ICT competence of pre-service teacher students. The research uses a quantitative approach which is carried out in the form of a survey to students of the Education Study Program as pre-service teachers and then interviews are carried out for the data triangulation process. The research subjects were pre-service teacher students at Universitas Negeri Semarang. The survey questionnaire was developed based on the indicators of teacher ICT competence according to UNESCO which consists of 6 aspects. The survey results show that both groups of respondents have good ICT competencies. However, after a more in-depth investigation of the triangulation data from the ICT competency interviews, preservice teachers who have obtained digital literacy learning are superior in aspects of understanding ICT in education, organization and administration, and teaching professional teachers. The influence of digital learning on the ICT competence of pre-service teachers in these three aspects becomes a recommendation for the implementation of digital literacy learning in universities that create pre-service teachers.
\end{abstract}

Keywords: digital literacy, ICT competence of pre-service teacher, 21st century learning

Abstrak: Saat ini guru dituntut memiliki kemampuan mengintegrasikan TIK dalam pembelajaran untuk menjawab tantangan pembelajaran di abad 21. Salah satu upaya untuk meningkatkan kompetensi TIK guru adalah dengan menerapkan pembelajaran literasi digital di perguruan tinggi yang mencetak lulusan calon guru. Penelitian ini bertujuan untuk mengetahui bagaimana pengaruh pembelajaran literasi digital pada kompetensi TIK mahasiswa calon guru. Penelitian menggunakan pendekatan kuantitatif berupa survei kepada mahasiswa Program Studi Kependidikan sebagai calon guru dan selanjutnya dilakukan wawancara untuk proses triangulasi data. Subjek penelitian adalah mahasiswa calon guru di Universitas Negeri Semarang. Hasil survey menunjukan kedua kelompok responden memiliki kompetensi TIK yang baik. Namun setelah diteliti lebih dalam dari data triangulasi hasil wawancara komptensi TIK, calon guru yang telah memperoleh pembelajaran literasi 
Prasetyo Listiaji \& Subhan subhan, Pengaruh Pembelajaran Literasi Digital pada Kompetensi Teknologi Informasi dan Komunikasi Calon Guru

digital lebih unggul pada aspek pemahaman TIK dalam pendidikan, organisasi, dan administrasi, dan pembejajaran guru profesional. Pengaruh pembelajaran digital terhadap kompetensi TIK calon guru pada ketiga aspek tersebut menjadi rekomendasi diterapkannya pembelajaran literasi digital pada perguruan tinggi yang mencetak calon guru.

Kata kunci: literasi digital, kompetensi TIK calon guru, pembelajaran abad 21

\section{PENDAHULUAN}

Saat ini dunia dihadapkan pada era revoluasi industri 4.0 dimana teknologi informasi dan komunikasi (TIK) berkembang sangat pesat. Kondisi ini menyebabkan perubahan pada hampir semua aspek kehidupan seperti ekonomi, sosial, maupun pendidikan (Shafie, Majid, \& Ismail, 2019). Pada aspek pendidikan, pelaku pendidikan dihadapkan pada karakteristik peserta didik saat ini yang sangat tergantung pada teknologi (Lemley, Schumacher, \& Vesey, 2014). Hal ini menuntut perubahan pada aspek pembelajaran yang kita kenal dengan pembelajaran abad 21 (Shafie, et al, 2019). Karakterisrik peserta didik abad 21 salah satunya adalah memanfaatkan TIK untuk belajar dan memperoleh pengetahuan. Fenomena ini sangat wajar karena keterampilan penggunaan TIK merupakan salah satu kompetensi penting yang diperlukan di era abad 21 selain kompetensi lainya seperti kreativitas, berpikir kritis, komunikasi, pemecahan masalah, keterampilan matematis, dan kolaborasi (Chalkiadaki, 2018). Untuk menjawab tantangan ini, guru dituntut tidak lagi menggunakan metode klasik dalam pembelajaran seperti penggunaan papan tulis di depan kelas, tetapi harus lebih terampil melakukan pembelajaran yang mendukung pencapaian kompetensi peserta didik abad 21 (Shafie, et al, 2019).

Memasuki abad 21, perkembangan teknologi dan pengetahuan yang begitu pesat harus diketahui oleh peserta didik secara tepat dan cepat. Kebutuhan ini perlu disikapi oleh guru untuk memfasilitasi peserta didik mengikuti perkembangan teknologi dan memperoleh berbagai macam sumber belajar memanfaatkan TIK (Anealka, 2018, Wolters \& Brady, 2020;
Listiaji, et al., 2020, 2021). Sehingga kemampuan guru memanfaatkan TIK dalam pembelajaran sangatlah diperlukan. Pembelajaran yang mengikuti tuntutan abad 21 akan dapat menyiapkan peserta didik yang dapat beradabtasi di dunia kerja khususnya pada aspek penggunaan TIK. Jika guru tidak memiliki kemampuan mengembangkan keterampilan abad 21 , peserta didik pun tidak dapat mengembangkan keterampilan tersebut (Shafie, et al, 2019).

Menyadari tuntutan abad 21, pemerintah melalui Undang-Undang Nomor 14 Tahun 2005 tentang guru dan dosen telah menetapkan kompetensi yang harus dimiliki oleh guru yaitu 1) Profesional, 2) Pedagogi 3) Kepribadian, dan 4) Sosial.

Keempat kompetensi tersebut cukup untuk menjawab tantangan pembelajaran abad 21 . Diperlukan pengetahuan dan keterampilan pendukung yaitu dalam hal mengitegrasikan TIK dalam pembelajaran yang dikenal dengan Technological Knowledge (TK) atau kompetensi TIK guru (Zhang, 2011). TK adalah kemampuan guru menggunakan teknologi sebagai alat bantu pembelajaran. Menjelaskan pengetahuan guru dan kemampuan untuk menggunakan berbagai teknologi, alat teknologi, dan sumber daya terkait. TK memperhatikan pemahaman tentang edtech, yaitu belajar mengenali kapan hal teknologi akan membantu atau menghalangi pembelajaran, dan terus belajar dan beradaptasi dengan penawaran teknologi baru (Cheng, 2017).

Untuk menjawab tantangan perlunya kompetensi TIK pada guru, The United Nations Educational, Scientific and Cultural Organization (UNESCO) telah membuat kerangka kerja 
kompetensi TIK untuk guru yang tertuang dalam dokumen ICT Competency Framework for Teachers (ICT CFT) (UNESCO, 2011). ICT CFT adalah suatu kerangka kerja yang berisi kompetensi guru untuk mengintegrasikan TIK dalam proses belajar-mengajar dan praktik profesional guru (Mtebe, 2020). ICT CFT dijadikan sebagai pedoman bagi negara-negara berkembang, yang salah satunya adalah Indonesia dalam membuat kebijakan dan standar kompetensi TIK guru nasional yang komprehensif. Kompetensi TIK guru ini meliputi semua guru secara umum dalam kaitannya dengan TIK. Kompetensi TIK guru tidak sama dengan kompetensi guru TIK. Menurut UNESCO, Kompetensi TIK guru dapat dikelompokkan ke dalam enam aspek, yaitu: 1) pemahaman TIK dalam pendidikan, 2) kurikulum dan penilaian, 3) pedagogi, 4) teknologi informasi dan komunikasi, 5) organisasi dan administrasi, dan 6) pembelajaran guru profesional (AnsongGyimah, 2017; UNESCO, 2011).

Sejalan kerangka kompetensi TIK guru yang dikembangkan oleh UNESCO. Pemerintah Indonesia melalui Peraturan Menteri Pendidikan Nasional Nomor 16 Tahun 2007 telah menetapkan kompetensi TIK bagi guru yang sekurang-kurangnya mempunyai dua fungsi, yaitu TIK sebagai pengembangan diri dan TIK sebagai penunjang proses pembelajaran (Menteri Pendidikan Nasional RI, 2007). Selain itu, perguruan tinggi eks LPTK juga ikut andil dalam meningkatkan komptensi TIK guru, salah satunya dengan menetapkan mata berbasis TIK bagi mahasiswa calon pendidik. Hal tersebut sangat bermanfaat bagi mahasiswa calon guru untuk melatih pengetahuan teknologi yang akan berguna untuk peran di masa depan sebagai guru profesional.

Penelitian terkait dengan Technological Knowledge ataupun kompetensi TIK guru atau calon guru sudah banyak dilakukan, di antaranya penyiapan calon guru untuk mengintegrasikan teknologi dalam pembelajaran melalui pendekatan technology-infused (Admiraal, et al, 2017). Batubara (2017) melakukan penelitian terkait kompetensi TIK guru, namun penelitian ini masih berupa studi pustaka terkait potret, faktor-faktor, dan upaya meningkatkannya. Selanjutnya Foulger, et al (2017) melakukan penelitian untuk seperangkat kompetensi teknologi mempersiapkan calon guru untuk mengajar dengan teknologi. Penelitian ini baru berupa tahap awal untuk mengidentikasi kompetensi guru yang terkait dengan teknologi. Penelitian terbaru dilakukan oleh Rubach dan Lazarides (2021) yaitu mengembangkan instrumen untuk menilai keyakinan kompetensi TIK pedagogis guru

Penelitian terkait juga telah dilakukan oleh Badia dan Iglesias (2019) yaitu menggali lebih dalam tentang konseptualisasi identitas guru di sekolah menengah mengenai penggunaan teknologi untuk pengajaran dan pembelajaran. Hasil mengungkapkan adanya korelasi yang kuat di antara mereka tentang teknologi dan kompetensi dalam menggunakan teknologi.

Penelitian terkait literasi digital yang telah dilakukan oleh Rusydiyah, Purwati, \& Prabowo (2020) tentang literasi digital sebagai sumber pembelajaran calon guru di Indonesia. Penelitian yang dilakukan Rusydiyah, et al (2020) hanya pengaruh literasi digital pada satu indikator TIK yaitu pemanfaatan TIK sebagai sumber pembelajaran. Berdasarkan uraian penelitan sebelumnya, belum ada studi yang secara spesifik terkait dengan pengaruh pembelajaran literasi digital pada kompetensi TIK calon guru. Kompetensi TIK yang dimaksud di sini adalah yang memenuhi kerangka komptensi TIK guru UNESCO.

Berdasarkan uraian di atas rumusan masalah pada penelitian ini adalah "Bagaimana pengaruh pembelajaran literasi digital terhadap kompetensi TIK bagi calon guru?" Kompetensi TIK ini meliputi 1) pemahaman TIK dalam pendidikan, 2) Kurikulum dan Penilaian, 3) Pedagogi, 4) Teknologi Informasi dan 
Komunikasi, 5) Organisasi dan Administrasi, dan 6) Pembelajaran guru profesional. Kompetensi TIK guru ini sekaligus untuk menjawab tantangan pembelajaran abad 21 di era revolusi industri 4.0.

\section{METODE}

Pendekatan penelitian yang digunakan adalah penelitian kuantitatif. Pada penelitian ini dideskripsikan tentang pengaruh pembelajaran literasi digital pada kompetensi TIK calon guru. Untuk mengetahui pengaruh ini dilakukan dengan memberikan survei kepada calon guru. Selanjutnya dilakukan wawancara untuk proses triangulasi data.

Subjek penelitian adalah calon guru pada Universitas Negeri Semarang sebagai salah satu perguruan tinggi eks LPTK. Responden survei terbagi dalam 2 kelompok yaitu kelompok mahasiswa yang telah menempuh matakuliah Literasi Digital dan Kemanusiaan (LDK) dan kelompok mahasiswa yang belum menempuh mata kuliah LDK. Setiap kelompok responden berjumlah 50 mahasiswa dengan teknik pemilihan sampel secara acak (random sampling). Waktu pengambilan data dilakukan pada bulan Desember 2020 hingga Maret 2021 secara daring melalui aplikasi Google Form.

Instrumen survei dikembangkan sesuai dengan ICT Competency Framework for Teachers UNESCO yang terdiri dari enam aspek yaitu 1) pemahaman TIK dalam pendidikan, 2) kurikulum dan penilaian, 3) pedagogi, 4) teknologi informasi dan komunikasi, 5) organisasi dan administrasi, dan 6) pembelajaran guru profesional (Ansong-Gyimah, 2017; UNESCO, 2011). Setiap aspek dijabarkan dalam lima pernyataan positif yang harus direspon oleh responden sehingga secara keseluruhan terdapat 30 pernyataan. Indikator pada setiap aspek dijelaskan pada Tabel 1.

Tabel 1 Indikator kompetensi TIK calon guru pada instrumen survey sesuai dengan ICT CFT

\begin{tabular}{|c|c|}
\hline Aspek & Indikator \\
\hline $\begin{array}{l}\text { Pemahaman TIK dalam } \\
\text { pendidikan }\end{array}$ & $\begin{array}{l}\text { Pemahaman guru terhadap kebijakan pemerintah dalam pendayagunaan } \\
\text { teknologi informasi dan komunikasi untuk pendidikan, sehingga guru } \\
\text { mampu menerjemahkan kebikan tersebut ke dalam praktek aktivitas } \\
\text { pembelajaran. }\end{array}$ \\
\hline Kurikulum dan Penilaian & $\begin{array}{l}\text { Pemanfaatan TIK dalam hal pengembangan kurikulum, pengelolaan } \\
\text { lingkungan belajar, pengelolaan pengalaman belajar siswa, penilaian } \\
\text { dan pengukuran, serta pemanfaatan TIK untuk peserta didik } \\
\text { berkebutuhan khusus. }\end{array}$ \\
\hline Pedagogi & $\begin{array}{l}\text { pemanfaatan TIK dalam hal perencanaan dan penyusunan strategi } \\
\text { pembelajaran, pengembangan pembelajaran aneka sumber, } \\
\text { pembelajaran berbasis masalah, serta komunikasi dan kolaborasi. }\end{array}$ \\
\hline $\begin{array}{l}\text { Teknologi Informasi dan } \\
\text { Komunikasi }\end{array}$ & $\begin{array}{l}\text { Kompetensi guru dalam penggunaan piranti TIK, baik pemanfaatan } \\
\text { multimedia, internet, media audio visual untuk pembelajaran ataupun } \\
\text { TIK sebagai penunjang administrasi pembelajaran. }\end{array}$ \\
\hline $\begin{array}{l}\text { Organisasi dan } \\
\text { Administrasi }\end{array}$ & $\begin{array}{l}\text { Integrasi TIK dalam pembelajaran, pengelolaan pembelajaran } \\
\text { berbantuan TIK, serta pemahaman tentang etika dalam pemanfaatan } \\
\text { TIK. }\end{array}$ \\
\hline $\begin{array}{l}\text { Pembelajaran guru } \\
\text { Profesional }\end{array}$ & $\begin{array}{l}\text { Kemampuan guru dalam memanfaatkan TIK untuk pengembangan diri, } \\
\text { partisipasi dan kontribusi dalam forum profesi, serta memanfaatkan TIK } \\
\text { sebagai sarana riset dan pengembangan professional. }\end{array}$ \\
\hline
\end{tabular}


Untuk setiap pernyataan responden memberikan respon keseuaian berupa angka rating 1 sampai 5 (bilangan bulat) sesuai dengan pengetahuan teknologi pada tiap aspek yang dimiliki oleh responden. Indikator rating kesesuaian yang diberikan adalah 1 (tidak sesuai), 2 (kurang sesuai), 3 (cukup sesuai), 4 (sesuai), dan 5 (sangat sesuai).

Metode wawancara dilakukan kepada seluruh responden secara kolektif melalui Zoom Meeting untuk mengonfirmasi jawaban responden pada survei sebagai data triangulasi.

Teknis analisis data yang digunakan model Miles dan Huberman (1994), yang mengemukakan bahwa kegiatan analisis data meliputi: 1) reduksi data (data reduction); 2) pemaparan data/kategorisasi (data display); dan 3) penarikan kesimpulan (conclusion drawing/ verification). Pada tahap reduksi data, data hasil survei dilakukan analisis skala likert dari hasil jawaban responden pada kuisioner. Hasil skor total responden $(X)$ kemudian dikonversi dalam persentase $(P)$ sesuai persamaan 1 (Suharsimi, 2013).

$$
P=\frac{\sum X}{N} \times 100 \%
$$

$\mathrm{N}$ adalah skor maksimal. Dari data kuesioner survei yang diperoleh kemudian ditransformasikan ke dalam kalimat kualitatif sebagai cara penafsiran hasil penelitian (Tabel 2 ).

Tabel 2 Kriteria Penafsiaran Hasil Survei Terkait Pengetahuan Teknologi

\begin{tabular}{cc}
\hline Rentang Presentase & Keterangan \\
\hline $20 \%-40 \%$ & Kurang \\
$41 \%-60 \%$ & Cukup \\
$61 \%-80 \%$ & Baik \\
$81 \%-100 \%$ & Sangat Baik \\
\hline
\end{tabular}

Pada tahap pemaparan data/kategorisasi, data hasil survei dilakukan kategorisasi sesuai kriteria kompetensi TIK Guru menurut UNESCO. Data hasil pemaparan dilakukan triangulasi menggunakan wawancara selanjutnya dilakukan penarikan kesimpulan.

\section{HASIL DAN PEMBAHASAN}

Hasil kompetensi TIK responden mahasiswa calon guru berdasarkan indikator kerangka komptensi TIK guru menurut UNESCO ditunjukkan pada Gambar 1.

Secara keseluruhan (overall) berdasarkan grafik pada Gambar 1 terlihat bahwa kompetensi TIK mahasiswa calon guru memperoleh kategori sangat baik. Namun mahasiswa yang telah menempuh pembelajaran literasi sedikit lebih tinggi yaitu $84,58 \%$ jika dibandingkan mahasiswa yang belum menempuhnya yaitu $82,46 \%$. Selisih yang hanya $2,12 \%$ menunjukkan bahwa pembelajaran literasi digital memiliki pengaruh terhadap kompetensi TIK calon guru walaupun sedikit. Selisih skor tersebut akan dianalisis lebih dalam menggunakan tringgulasi hasil wawancara untuk mengetahui deskripsi kualitatif kompetensi TIK pada setiap aspeknya.

\section{Aspek Pemahaman TIK dalam Pendidikan}

Aspek pemahaman TIK dalam pendidikan berisi pemahaman guru terhadap kebijakan pemerintah dalam pendayagunaan teknologi informasi dan komunikasi untuk pendidikan, sehingga guru mampu menerjemahkan kebijakan tersebut ke dalam praktik aktivitas pembelajaran (UNESCO, 2011; Mtebe, 2020; Ansong-Gyimah, 2017). Analisis berdasarkan hasil wawancara menunjukkan mahasiswa calon guru telah memahami pentingnya integrasi TIK dalam pembelajaran untuk menjawab tantangan pembelajaran di era abad 21 . Pengaruh pembelajaran literasi digital terlihat pada mahasiswa yang telah menempuh pembelajaran literasi digital. Mereka lebih memahami kebijakan-kebijakan terkait kompetensi TIK yang harus dimiliki oleh guru seperti kerangka kompetensi TIK guru menurut UNESCO, Peraturan Menteri Pendidikan Nasional Nomor 16 Tahun 2007, dan kebijakan perguruan tinggi yang tertuang dalam Capaian Pembelajaran Lulusan di Kurikulum Program Studi Kependidikan. Analisis lebih rinci menunjukkan bahwa 


\section{Sudah LDK $\square$ Belum LDK}

$100.00 \%$

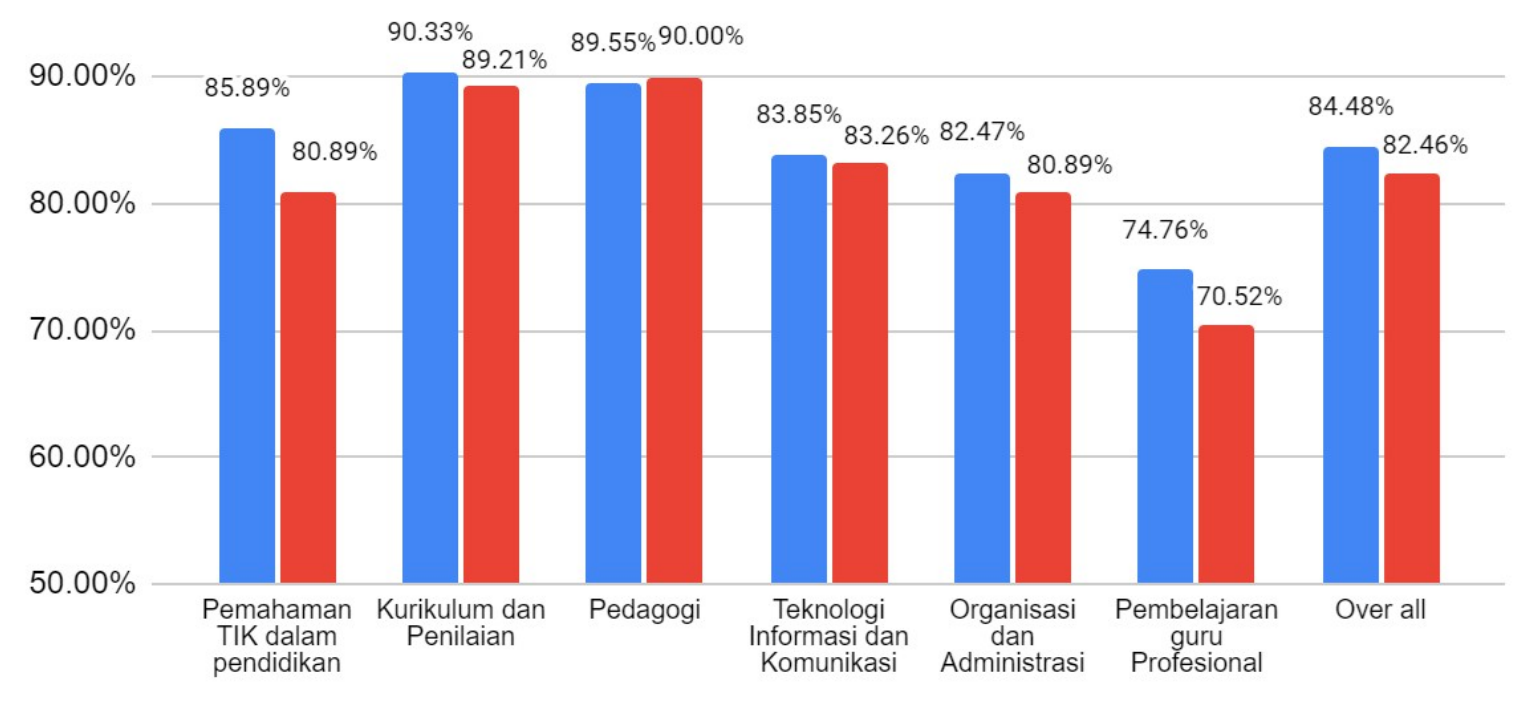

Aspek Kompetensi TIK guru

Gambar 1 Data Hasil Survei Kompetensi TIK Mahasiswa Calon Guru

pembelajaran literasi digital mengajarkan literasi informasi atau membantu mahasiswa calon guru mencari, memahami, dan memanfaatkan sumber informasi digital. Hal tersebut sesuai dengan hasil penelitian Nahdi dan Jatisunda (2020) dan Asari, et al, (2019) yaitu pembelajaran literasi digital meningkatkan literasi teknologi siswa. Informasi digital yang dimaksud pada indikator ini adalah kebijakan-kebijakan yang berhubungan dengan kompetensi TIK yang harus dimiliki oleh guru. Penelitian serupa dilakukan oleh Becker (2018) yang menyatakan bahwa dengan kemampuan literasi digital yang baik akan meningkatkan literasi informasi di era digital seperti saat ini.

\section{Aspek Kurikulum dan Penilaian}

Aspek kurikulum dan penilaian meliputi pemanfaatan TIK dalam hal pengembangan kurikulum, pengelolaan lingkungan belajar, pengelolaan pengalaman belajar siswa, penilaian dan pengukuran, serta pemanfaatan TIK untuk peserta didik berkebutuhan khusus (UNESCO, 2011; Mtebe, 2020; Ansong-Gyimah, 2017).
Hasil triangulasi dari wawancara diperoleh data bahwa mahasiswa calon guru dari kedua kelompok responden telah menyadari bahwa pemanfaatan TIK harus dimasukkan dalam kurikulum pembelajaran di sekolah. Responden juga terbiasa menggunakan TIK untuk membentuk lingkungan belajar siswa seperti memberikan stimulus dan motivasi belajar menggunakan video maupun animasi sebelum pembelajaran. Hal tersebut dilakukan saat menempuh mata kuliah praktik mengajar atau microteaching. Selain itu, pada indikator penggunaan TIK untuk evaluasi pembelajaran, mereka terbiasa menggunakan aplikasi kuis online seperti Quiziz, Kahoot, dan Google Form (Darmawan, Daeni, \& Listiaji, 2020). Sedangkan indikator pemanfaatan TIK untuk siswa berkebutuhan khusus telah dipelajari pada matakuliah yang berhubungan dengan pembelajaran inklusi.

Hasil jawaban responden yang lebih mendalam menunjukkan bahwa semua indikator kompetensi TIK calon guru pada aspek kurikulum dan penilaian tidak mereka peroleh pada 
pembelajaran linterasi digital. Kompetensi TIK pada aspek ini bersifat teknis sehingga menurut mereka secara kurikulum diperoleh pada mata kuliah yang berhubungan langsung dengan aspek kurikulum dan pembelajaran seperti Kajian Kurikulum, Evaluasi Pembelajaran, dan Media Pembelajaran.

Hal ini sesuai dengan penelitian Falloon (2020) yang menyatakan bahwa pembelajaran literasi digital yang berdiri sendiri tidak menjamin meningkatkan keterampilan teknis digital pada guru karena hanya berperan pada peningkatan wawasan konseptual terkait integrasi TIK dalam pembelajaran. Oleh karena itu, mahasiswa calon guru belum memperoleh keterampilan teknis penggunaan TIK pada aspek kurikulum dan penilaian pada pembelajaran literasi digital.

\section{Aspek Pedagogi}

Kompetensi TIK guru pada aspek pedagogi memuat tentang pemanfaatan TIK dalam hal perencanaan dan penyusunan strategi pembelajaran, pengembangan pembelajaran aneka sumber, pembelajaran berbasis masalah, serta komunikasi dan kolaborasi (UNESCO, 2011; Mtebe, 2020; Ansong-Gyimah, 2017). Pada penelitian ini dijabarkan dalam lima indikator (Tabel 4).

Pada aspek pedagogi, kedua kelompok responden memilki kompetensi TIK pada aspek pedagogi yang baik. Hasil wawancara menunjukkan bahwa pada aspek pedagogi responden terbiasa menuliskan integrasi TIK pada rencana pelaksanaan pembelajaran (RPP), memanfaatkan media internet sebagai sumber belajar tambahan siswa, memanfaatkan gawai dan sosial media sebagai sarana kolaborasi dan komunikasi pembelajaran, dan memanfaatkan internet untuk mengembangkan pembelajaran.

Hasil wawancara juga menunjukkan bahwa indikator kompetensi TIK guru pada aspek pedagogi justru tidak diajarkan pada pembelajaran literasi digital melainkan pada mata kuliah perencanaan pembelajaran. Faktor lain yang mendukung kompetensi TIK yang baik pada aspek ini adalah responden termasuk dalam generasi native digital yaitu generasi yang hidup pada era digital dimana internet menjadi bagian dari keseharian dalam hidupnya (Diputra, Tristiantari, \& Jayanta, 2020). Dalam aspek pedagogi secara otomatis, para calon guru sudah memiliki pengetahuan dan kompetensi memanfaatkan dunia digital untuk merencanakan pembelajaran, mencari aneka sumber belajar, kolaborasi, dan komunikasi.

\section{Aspek Teknologi Informasi dan Komunikasi}

Pada aspek TIK berisi tentang kompetensi guru dalam penggunaan piranti TIK, baik pemanfaatan multimedia, internet, media audio visual untuk pembelajaran ataupun TIK sebagai penunjang administrasi pembelajaran.

Pada aspek ini, kedua kelompok responden telah terampil mencari sumber belajar dari internet, membuat dan menggunakan media pembelajaran interaktif berbasis TIK seperti membuat slide interaktif, video pembelajaran, dan laboratorium maya menggunakan software pengolah kata MS Word dan pengolah angka seperti Excel yang dapat menunjang kinerja administrasi dan menggunakan online assessment yang memudahkan untuk memberikan penilaian hasil belajar siswa.

Hasil wawancara dengan mahasiswa calon guru bahwa mereka memperoleh kompetensinya dalam teknis penggunaan TIK dalam pembelajaran yaitu pada mata kuliah Pengembangan Media Pembelajaran. Pembelajaran literasi digital tidak mengajarkan kompetensi teknis tetapi lebih bersifat pengetahuan untuk menggunakan media digital, alat-alat komunikasi, atau jaringan dalam menemukan, mengevaluasi, menggunakan, membuat informasi, dan memanfaatkannya secara sehat, bijak, cerdas, cermat, tepat, dan patuh hukum (Hanik, 2020). 


\section{Aspek Organisasi dan Administrasi}

Aspek organisasi dan administrasi memuat integrasi TIK dalam pembelajaran, pengelolaan pembelajaran berbantuan TIK, serta pemahaman tentang etika dalam pemanfaatan TIK.

Pada aspek ini, kedua kelompok responden telah mampu menentukan topik pembelajaran yang membutuhkan integrasi TIK, terampil mengatur waktu yang tepat untuk menggunakan TIK pada pembelajaran, memahami etika penggunaan TIK dalam pembelajaran, sekaligus memahamkan siswanya terkait etika tersebut. Bedasarkan wawancara lanjutan diperoleh data bahwa mahasiswa yang telah memperoleh pembelajaran literasi digital memiliki pengetahuan terkait pengelolaan dan etika TIK lebih baik seperti pemahaman tentang Undang undang tentang Informasi dan Transaksi Elektronik (UU ITE). Hal tersebut sesuai dengan penelitian Ginting, Arindani, dan Lubis (2021) yang mengatakan bahwa literasi digital meningkatkan pemahaman etika penggunaan internet dan yang mengaturnya seperti UU ITE. Hal senada juga disebutkan dalam penelitian Julien, et al. (2020) bahwa literasi digital meningkatkan keterampilan, pengetahuan, dan sikap yang diperlukan untuk mengakses informasi digital secara efektif, efisien, dan etis.

\section{Aspek Pembelajaran Guru Profesional}

Aspek terakhir berisi tentang kemampuan guru dalam memanfaatkan TIK untuk pengembangan diri, partisipasi dan kontribusi dalam forum profesi, serta memanfaatkan TIK sebagai sarana riset dan pengembangan profesional.

Pada aspek responden mahasiswa calon guru yang telah memperoleh pembelajaran literasi digital memiliki kompetensi lebih baik seperti terbiasa menggunakan Google Scholar dan Scopus untuk mencari referensi penelitian. Mereka aktif mengikuti forum diskusi ilmiah pendidik dengan memanfaatkan media internet dan media social. Mereka juga mengikuti pelatihan dan kompetisi yang berhubungan dengan pemanfaatan TIK dalam pembelajaran, dan aktif menulis gagasan terkait pembelajaran melalui media sosial ataupun media elektronik lainya.

Kompetensi yang paling unggul pada calon guru yang telah menempuh pembelajaran literasi digital adalah pada indikator menulis gagasan terkait pembelajaran melalui media sosial ataupun media elektronik lainya. Penelitian Mauludin dan Cahyani (2018) menyatakan bahwa pembelajaran literasi digital memberikan pengetahuan bagaimana memanfaatkan media digital seperti media sosial untuk menulis gagasan-gagasan konstruktif. Hal ini diterapkan oleh responden yang telah menempuh pembelajaran literasi digital untuk aktif menulis gagasan dalam media sosial terkait pembelajaran.

\section{SIMPULAN DAN SARAN \\ Simpulan}

Pengaruh pembelajaran literasi digital pada kompetensi TIK calon guru terdapat pada aspek pemahaman TIK dalam pendidikan, organisasi dan administrasi, dan pembelajaran guru profesional. Pada aspek pemahaman TIK dalam pendidikan, pembelajaran literasi digital berperan mengajarkan literasi informasi terkait kebijakankebijakan integrasi TIK dalam pembelajaran. Pada aspek organisasi dan administrasi, membantu calon guru memahami etika penggunaan internet dalam pembelajaran dan peraturan-peraturan yang mengaturnya. Sedangkan pada aspek pengembangan guru profesional, literasi digital memberikan pengetahuan dalam memanfaatkan media digital menulis gagasan-gagasan konstruktif tentang pembelajaran.

\section{Saran}

Pengaruh pembelajaran digital terhadap kompetensi TIK calon guru pada aspek pemahaman TIK dalam pendidikan, organisasi dan administrasi, dan pembejajaran guru 
profesional menjadi rekomendasi diterapkannya pembelajaran literasi digital pada perguruan tinggi yang mencetak calon guru.

Selanjutnya sebagai bahan untuk memperkaya kajian penelitian ini, perlu dilakukan lebih lanjut terkait pengaruh pembelajaran literasi digital terhadap kompetensi TIK calon guru dengan melibatkan analisis kurikulum pembe- lajaran literasi digital di perguruan tinggi. Analisis kurikulum diperlukan untuk memperoleh jawaban lebih detail pengaruh literasi digital pada aspek kurikulum dan pembelajaran, peda-gogi, dan teknologi informasi dan komunikasi yang belum nampak pada penelitian ini.

\section{PUSTAKA ACUAN}

Admiraal, W., van Vugt, F., Kranenburg, F., Koster, B., Smit, B., Weijers, S. and Lockhorst, D., (2017). Preparing pre-service teachers to integrate technology into $\mathrm{K}-12$ instruction: evaluation of a technology-infused approach. Technology, Pedagogy and Education, 26(1), 105-120.

Anealka Aziz, H. (2018). Education 4.0 made simple: Ideas for teaching. International Conference of Economic and Management Processes, 6(3), 92-98.

Ansong-Gyimah, K.(2017). Creating an online tool for assessing the readiness of teacher training colleges in developing countries to implement the UNESCO ICT competency framework for teachers: A design and development study. Doctoral dissertation, Virginia Tech.

Asari, A., Kurniawan, T., Ansor, S, \& Putra, A.B.N.R.(2019). Kompetensi literasi digital bagi guru dan pelajar di lingkungan sekolah kabupaten Malang. BIBLIOTIKA: Jurnal Kajian Perpustakaan dan Informasi, 3(2), 98-104.

Badia, A. \& Iglesias, S. (2019). The science teacher identity and the use of technology in the classroom. Journal of Science Education and Technology, 28(5), 532-541.

Batubara, D.S.(2018). Kompetensi Teknologi Informasi dan Komunikasi Guru SD/MI (Potret, Faktor-faktor, dan Upaya Meningkatkannya). Muallimuna: Jurnal Madrasah Ibtidaiyah, $\underline{3}(1), 48-65$.

Becker, B.W.(2018). Information literacy in the digital age: Myths and principles of digital literacy. School of Information Student Research Journal, 7(2), 2.

Chalkiadaki, A.(2018). A systematic literature review of 21 st century skills and competencies in primary education. International Journal of Instruction, 11(3), 1-16.

Cheng, K.H.(2017). A survey of native language teachers' technological pedagogical and content knowledge (TPACK) in Taiwan. Computer Assisted Language Learning, 30(7), 692-708.

Darmawan, M. S., Daeni, F., \& Listiaji, P. (2020). The Use of Quizizz As An Online Assessment Application for Science Learning in The Pandemic Era. Unnes Science Education Journal, 9(3), 144-150.

Diputra, K.S., Tristiantari, N.K.D., \& Jayanta, I.N.L.(2020). Gerakan literasi digital bagi guru-guru sekolah dasar. Journal of Character Education Society, 3(1), 118-128.

Falloon, G.(2020). From digital literacy to digital competence: the teacher digital competency (TDC) framework. Educational Technology Research and Development, 68(5), 24492472. 
Prasetyo Listiaji \& Subhan subhan, Pengaruh Pembelajaran Literasi Digital pada Kompetensi Teknologi Informasi dan Komunikasi Calon Guru

Foulger, T.S., Graziano, K.J., Schmidt- Crawford, D., \& Slykhuis, D.A.(2017). Teacher educator technology competencies. Journal of Technology and Teacher Education, 25(4), 413448.

Ginting, R.V.B., Arindani, D., Lubis, C.M.W. and Shella, A.P.(2021). Literasi Digital sebagai wujud pemberdayaan masyarakat di era globalisasi. Jurnal Pasopati: Pengabdian Masyarakat dan Inovasi Pengembangan Teknologi, 3(2).

Hanik, E.U.(2020). Self directed learning berbasis literasi digital pada masa pandemi covid-19 di madrasah ibtidaiyah. ELEMENTARY: Islamic Teacher Journal, 8(1), 183-208.

Julien, H., Latham, D., Gross, M., Moses, L., \& Warren, F.(2020). Information Literacy Practices and Perceptions of Community College Librarians in Florida and New York. Communications in Information Literacy, 14(2), 7.

Lemley, J. B., Schumacher, G., \& Vesey, W. (2014). What learning environments best address 21st-century students' perceived needs at the secondary level of instruction? NASSP Bulletin, 98, 101-125.

Listiaji, P., Darmawan, M. S., \& Daeni, F. (2020). Comparison between the use of acceleration sensor and video tracker on smartphone for spring oscillation experiment. Physics Education, 56(1), 013001.

Listiaji, P., Subhan, S, \& Daeni, F.(2021). Error analysis in measuring physical quantities using various sensors on a smartphone. Physics Education, 56(4),043006.

Mauludin, S. \& Cahyani, I.(2018). Literasi digital dalam pembelajaran menulis. In Seminar Internasional Riksa Bahasa (1273-1282).

Mtebe, J.S.(2020). Applying UNESCO ICT competency framework to evaluate teachers' ICT competence levels in Tanzania. In Handbook of Research on Innovative Pedagogies and Best Practices in Teacher Education (350-366). IGI Global.

Nahdi, D.S. \& Jatisunda, M.G. (2020). Analisis literasi digital calon guru SD dalam pembelajaran berbasis virtual classroom di masa pandemi covid-19. Jurnal Cakrawala Pendas, 6(2).

Rubach, C. \& Lazarides, R.(2021). Addressing 21st-century digital skills in schools-Development and validation of an instrument to measure teachers' basic ICT competence beliefs. Computers in Human Behavior, 118, 106636.

Rusydiyah, E.F., Purwati, E. \& Prabowo, A.(2020). How to use digital literacy as a learning resource for teacher candidates in Indonesia. Jurnal Cakrawala Pendidikan, 39(2), 305318.

Shafie, H., Majid, F. A., \& Ismail, I. S. (2019). Technological pedagogical content knowledge (TPACK) in teaching 21 st century skills in the 21 st century classroom. Asian Journal of University Education, 15(3), 24-33.

Suharsimi, A.(2013). Prosedur penelitian, Jakarta: PT. Rineka Cipta.

UNESCO. (2011). UNESCO ICT competency framework for teachers.

Wolters, C.A. \& Brady, A.C.(2020). College students' time management: A self-regulated learning perspective. Educational Psychology Review, 1-33.

Zhang, B.H. (2011). CK, PCK, TPCK, and non-intellectual factors in sustaining an iMVT innovation for Science learning. Procedia - Social and Behavioral Sciences, 15, 21422147. 